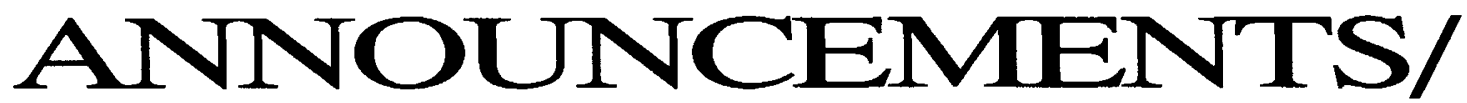

\section{DECEMBER MEETINGS}

Dec. 9-11. Int'l. symposium on advances in delivery of therapeutic and diagnostic agents. Sydney, Australia. Info: CRS Administrative Office, 1020 Milwaukee, Suite 235, Deerfield, IL 60015. Tel: 708-808-7071.

Dec. 15-16. Profiting in the managed prescribing market. Washington, DC. Info: Infoline, 225 Turnpike Rd., Southborough, MA 01772-1749. Tel: 508-481-6400.

\section{COURSES AND WORKSHOPS}

Dec. 7-8. Experimental design and analysis. Pittsburgh, PA. Info: Barbara Sherman, PACS, 409 Meade Dr., Coraopolis, PA 15108. Tel: 412-457-6576 or $800-367-2587$.

Dec. 7-9. Isolation, analysis, and characterization of proteins. New Brunswick, NJ. Info: Office of Continuing Professional Education, Rutgers University-Cook College, P.O. Box 231, New Brunswick, NJ 08903-0231. Tel: 908-932-9271

Dec. 7-9a. Electrochemical techniques for corrosion measurement. Hunt Valley, MD. Info: Cynthia Nienart, EG\&G Princeton Applied Research, P.O. Box 2565, Princeton, NJ 08543. Tel: 609-530-1000.

Dec. 8-11. DNA fingerprinting. Rockville, MD. Info:ATCC/Workshop Manager, 12301 Parklawn Dr., Rockville, MD 20852. Tel: 301231-5566.

Dec. 9-10. Quality assurance chemical measurements. Pittsburgh, PA. Info: see Dec. 78.

Dec. 10-15. Identification and computer control of industrial plants. Queluz, Portugal. Info: Forbitec-UETP, c/o Lneti, Estrada das Palmeiras, Queluz de Baixo, 2745 Queluz, Portugal. Tel: 351-1-436-0079.

Dec. 10-18. Introduction of genetically modified organisms into the environment: biosafety aspects. Wageningen, the Netherlands. Info: EERO Training Centre, P.O Box 182, 6700 AD Wageningen, the Netherlands. Tel: 31-8370-84924.

Dec. 14-15. Filter integrity testing operator training and certification program. Bedford, MA. Info: Kathy Dykeman, Millipore Bedford, MA 01730. Tel: 617-275-9211, ext. 2435.

Dec. 14-18. Advanced recombinant DNA methodology. Rockville, MD. Info: see Dec. 8-11.

Dec. 15. Introduction to PCR. Gainesville, FL. Info: Susannah Chance, Biotechnology Training Programs, 301 Main St., Suite \#3, Ames, IA 50010. Tel: 800-821-4861.

Dec. 16-18. Cloning \& hybridization analysis of PCR products. Gainesville, FL. Info: see Dec. 15.

Dec. 15-17. Understanding the principles of heat transfer and heat exchanger design. Madison, WI. Info: Elaine Bower, University of Wisconsin-Madison, Dept. of Engineering Professional Development, 432 N. Lake St., Madison, WI 53706. Tel: 800-462-0876.

Jan. 4-7. Recombinant DNA techniques: an introductory lab course. New Brunswick, NJ. Info: see Dec. 7-9.

Jan. 6-8. Pilot plant studies and process scaling for batch and semi-batch processing. Lake Buena Vista, FL. Info: see Dec. 15-17.

Jan. 10-15. Protein purification, isolation, analysis, and characterization. New Brunswick, NJ. Info: see Dec. 7-9.

\section{EXECUTIVE CHANGES}

Embrex (Research Triangle Park, NC) appointed C. Crawford Carter director of sales and David Baines director of European operations.

Ligand Pharmaceuticals (San Diego, CA) named Alex M. Nadzan senior director of medicinal chemistry.

Calgene (Davis, CA) named Julianne Lindemann to its regulatory affairs team.

SyStemix (Palo Alto, CA) appointed Stephen $G$. Marcus vice president of medical and regulatory issues, Sue Gilbert chief financial officer, and Didier Lanson vice president of European operations.

Quintiles (Neuilly-sur-Seine, France) named Emmanuelle Voison director of strategic drug development.

MedClone (Los Angeles, CA) appointed Martin L. Lee director of regulatory affairs and clinical programs.

Affinity Biotech (Boothwyn, PA) appointed Nathan R. Tzodikov director of analytical sciences.

Advanced Tissue Sciences (La Jolla, CA) named Gary D. Gentzkow senior director of clinical research.

Cytel (San Diego, CA) appointed Karin Eastham vice president of finance and administration and chief financial officer

Telor Ophthalmic Pharmaceuticals (Woburn, MA) appointed Sophann Im manager of pharmaceutical development.

ImmunoGen (Cambridge, MA) named Dixie Esseltine director of oncology.

Arcturus Pharmaceutical (Woburn, MA) named Richard J. Sharpe senior vice president of research, development, and clinical affairs, and Rex Bright president and chief executive officer.

Isis Pharmaceuticals (Carlsbad, CA) named Jacqueline G. Siegel chief financial officer.

Amgen (Thousand Oaks, CA) named Kevin Sharer president and chief operating officer.
DepoTech (La Jolla, CA) named John P. Longenecker seniorvice president of research and development, Stephen B. Howell medical director, and Sinil Kim vice president of technology.

Macronex (Research Triangle Park, NC) appointed Dennis D. Burns president and chief executive officer.

AgriDyne Technologies (Salt Lake City, UT) promoted Timothy $\mathrm{E}$. Wood to vice president of research and development.

American Biogenetic Sciences (Notre Dame, IN) appointed Kenneth $\mathrm{H}$. Burk president and chief operating officer.

Besselaar (Princeton, NJ) named Gary Ingenito executive director of clinical research.

Nalge (Rochester, NY) appointed Roger Merrifield vice president of European operations.

Allelix Biopharmaceuticals (Toronto, Canada) appointed Suman Rakhit director of medicinal chemistry.

American Industrial Hygiene (Akron, $\mathrm{OH}$ ) named Jeffrey Seckler manager of public relations and marketing.

ChemTrak (Sunnyvale, CA) appointed Victor Y.S. Liu vice president of research and development and Alexander Monte manufacturing program manager.

T.E.A.M. (Toronto, Canada) named Scott Browning applications manager to its Science T.E.A.M. division.

Selectide (Tucson, AZ) appointed Bruce E. Seligmann vice president of research.

Olympus (Lake Success, NY) named Stephen Weiss vice president and division manager of its clinical instruments division.

ESCAgenetics (San Carlos, CA) appointed Peter J. Hylands vice president and chief scientist of its phytopharmaceuticals subsidiary.

BioSurface Technology (Cambridge, MA) promoted Elma Hawkins to director of clinical research, Susan Schaeffer to director of development, and Peter Courossi to director of finance and accounting.

Xenova (London) named Maria Ines Chicarelli-Robinson head of its natural products chemistry department.

Quality Biotech (Camden, NJ) appointed Alexander F. Sito senior vice president of research.

RhoMed (Albuquerque, NM) appointed Buck A. Rhodes president and chief executive officer.

bioMérieuxVitek (St. Louis, MO) appointed Kunio E. Suzuki president and chief operating officer. 